IP $\rightleftharpoons$ B

\title{
Viability of embryonic axes of Araucaria angustifolia after freezing using two cryopreservation methods
}

\author{
Caroline Frizzo ${ }^{1 *}(\mathbb{D})$, Marguerite Quoirin²(i) \\ ${ }^{1}$ Universidade Federal do Paraná, Rua dos Funcionários, 1540, CEP 80035-050, Curitiba, PR, Brazil \\ ${ }^{2}$ Universidade Federal do Paraná, Av. Coronel Francisco H. dos Santos, s/n., CEP 81531-980, Curitiba, PR, Brazil
}

"Corresponding author:

eng.carolinefrizzo@gmail.com

Index terms:

Dehydration

Encapsulation

Liquid nitrogen

Termos para indexação:

Desidratação

Encapsulamento

Nitrogênio líquido

Received in 19/09/2017

Accepted in 06/06/2018

Published in 07/12/2018

doi: 10.4336/2018.pfb.38e201701498

\begin{abstract}
Araucaria angustifolia (Bertol.) O. Kuntze is one of the most important native species in Southern Brazil. However, its naturally recalcitrant seeds represent obstacles for long-term conservation and thus cryopreservation is a viable alternative for germplasm storing. Embryonic axes (EA) excised from araucaria seeds were encapsulated, dehydrated, and submitted to two cryopreservation methods: flash-cooling by freezing in liquid nitrogen (LN) for $2 \mathrm{~h}$ and pre-cooling at $-40{ }^{\circ} \mathrm{C}$, followed by freezing in LN for $2 \mathrm{~h}$. Subsequently, the EA were quickly thawed and assessed for DNA integrity, tetrazolium test, in vitro germination and oxidation occurrence. The DNA of both not cryopreserved and cryopreserved EA maintained their integrity. The tetrazolium test results indicated that the majority of flash-cooled EA were viable. After 15 days of in vitro culture, the EA did not germinate and presented signs of oxidation. Dehydration method by direct plunge in LN is promising for cryopreservation of araucaria EA, as demonstrated through the results of tetrazolium test and the maintenance of total DNA integrity.
\end{abstract}

\section{Viabilidade de eixos embrionários de Araucaria angustifolia após o uso de dois métodos de criopreservação}

Resumo - Araucaria angustifolia (Bertol.) O. Kuntze é uma das espécies nativas do Brasil com maior importância na Região Sul. No entanto, suas sementes são recalcitrantes, constituindo um obstáculo para a sua conservação em longo prazo, sendo a criopreservação uma alternativa viável para o armazenamento de seu germoplasma. Os eixos embrionários (EE) excisados das sementes de araucária foram encapsulados, desidratados e submetidos a dois métodos de criopreservação: o resfriamento rápido, congelando em nitrogênio líquido (NL) durante $2 \mathrm{~h}$, e o pré-resfriamento a - $40{ }^{\circ} \mathrm{C}$, seguido do congelamento em nitrogênio líquido durante $2 \mathrm{~h}$. Posteriormente, os EE foram descongelados rapidamente e avaliados quanto à integridade do DNA pelo teste bioquímico do tetrazólio, germinação in vitro e ocorrência de oxidação. Tanto o DNA dos EE que não foram criopreservados quanto o daqueles que foram criopreservados mantiveram sua integridade. Os resultados do teste de tetrazólio indicaram que a maioria dos EE desidratados pelo congelamento rápido permaneceu viável. Após 15 dias de cultivo in vitro, os EE não germinaram e apresentaram sinais de oxidação. Os métodos de encapsulamento-desidratação seguidos de congelamento rápido são promissores para a criopreservação de EE de araucária, como demonstrado pelo teste de tetrazólio e da manutenção da integridade total do DNA. 


\section{Introduction}

In Brazil, the haphazard exploitation of the Ombrophilous Mixed Forest (Araucaria Forest) resulted in a drastic reduction in Araucaria angustifolia population, a species which dominates this type of forest (Maran et al., 2016; Pelissari et al., 2016; Gasparin et al., 2017). A. angustifolia (commonly called araucaria) is the only species of Araucaria genus that occurs naturally in Brazil and it has significant economic and ecological values. It is known for its high-quality wood and its seeds, popularly known as pinhões that are consumed by both humans and animals (Elbl et al., 2014; Zanette et al., 2017). Nowadays, the Ombrophilous Mixed Forest is reduced to almost $2 \%$ of its original area and araucaria is now considered an endangered species (Thomas, 2013; Zanette et al., 2017).

Araucaria seeds are recalcitrant and therefore difficult to preserve (Gasparin et al., 2017; Zanette et al., 2017). Despite its quick loss of viability after desiccation, they remain metabolically active (Berjak \& Pammenter, 2013; Pammenter \& Berjak, 2014). Cryopreservation, which consists of freezing plant tissue to a temperature of $-196{ }^{\circ} \mathrm{C}$, is the most suitable method for the conservation of recalcitrant seeds (Pammenter \& Berjak, 2014) and it is the ideal method for preserving germplasm as it requires minimal space and little maintenance (Pammenter \& Berjak, 2014; Kwaśniewska et al., 2017). At low temperatures, the metabolism of the cells is reduced, deterioration of the plant material does not occur, and after thawing, metabolic activities return to normal (Bandupriya et al., 2007; Tahtamouni et al., 2015; Sershen et al., 2016), maintaining their characteristics during cryopreservation (Shibli et al., 2016; Shahab et al., 2017).

Cryopreservation protocols for numerous plant species and plant parts have been developed (Santos, 2001; González-Benito et al., 2016). These protocols considered two freezing phases: the first consisted of a slow cooling to a pre-freezing temperature, at a defined cooling-rate between 1 and $10{ }^{\circ} \mathrm{C} \mathrm{h}^{-1}$, using a programmable freezer and the second involved direct immersion in liquid nitrogen (LN) (Pammenter \& Berjak, 2014; Jaganathan et al., 2017). The slow cooling process impedes the formation of ice crystals in the cells (Pammenter \& Berjak, 2014) by cryodehydration. Techniques based on vitrification, or formation of a vitreous state, have also been used in which water undergoes a transition from a liquid phase to an amorphous, metastable solid state, thus avoiding the formation of ice crystals. The transition to a vitrified state does not involve chemical changes but rather physical changes in the viscosity of the liquid (Santos, 2001; Pammenter \& Berjak, 2014; Shibli et al., 2016).

The cryopreservation techniques using vitrification that have been discussed in the literature include: encapsulation with dehydration; simple vitrification; encapsulation with vitrification; dehydration; pregrowth; pre-growth desiccation and droplet-freezing (Niino \& Arizaga, 2015; Matsumoto, 2017).

The method of encapsulation and dehydration is based on production of synthetic seeds, in which embryos are inserted in sodium alginate beads (Niino \& Arizaga, 2015; Matsumoto, 2017). Recent development in this protocol has facilitated cryopreservation techniques (Shibli et al., 2016; Matsumoto, 2017). Pre-culturing the plant material by encapsulating it in a medium enriched with sucrose before dehydration enables for greater resistance to dehydration and freezing (Bandupriya et al., 2007). The sugar pre-treatment partially dehydrates the plant material before exposure to low temperatures (Santos, 2001).

Cryopreservation has already been established for A. angustifolia embryogenic cultures but never for embryonic axes (EA) (Demarchi et al., 2014; Fraga et al., 2016). The mature embryos of this conifer are large (about $2.5 \mathrm{~cm}$ in length), contain more than $1 \mathrm{~g} \mathrm{H}_{2} \mathrm{O} \mathrm{g}^{-1}$ dry mass and are killed by drying (Pieruzzi et al., 2011). These morphological and physiological traits hinder the preservation of the whole embryos for ex situ conservation.

The objective of the current study was to evaluate the response of EA of $A$. angustifolia to encapsulation and dehydration in order to define an effective cryopreservation protocol for this species.

\section{Material and methods}

\section{Plant material}

Ripe araucaria seeds were collected from Embrapa Forestry progenies in the research area located in Colombo, Parana State, Brazil (2519'14'S 4909'43”'W). During the study period, the collected seeds were stored in $20 \mu \mathrm{m}$ thick, transparent plastic bags in a cold chamber at $5{ }^{\circ} \mathrm{C}$ and $89 \%$ of relative humidity. 


\section{Disinfection and preparation}

The seed coats were removed and the seeds disinfected in a 3\% sodium hypochlorite and $1 \%$ Tween ${ }^{\circledR} 20$ solution for $20 \mathrm{~min}$. Subsequently, the seeds were washed three times with autoclaved distilled water. With the use of scalpel and forceps, the embryonic axes (EA) and cotyledons were removed and placed on Petri dishes containing moistened filter papers to avoid the loss of humidity.

For encapsulation, EA without cotyledons were placed in a solution of MS salts and vitamins (Murashige \& Skoog, 1962) supplemented with $0.4 \mathrm{M}$ sucrose and $3 \%$ sodium alginate for $15 \mathrm{~min}$. EA were then retrieved and transferred to a sterile solution of $100 \mu \mathrm{M} \mathrm{CaCl}_{2}$ for $30 \mathrm{~min}$ to produce the alginate beads that were then washed with sterile distilled water to remove any excess of $\mathrm{CaCl}_{2}$.

\section{Osmoprotection}

Beads containing one EA were placed in a sterile MS salts and vitamin solution supplemented with $0.7 \mathrm{M}$ sucrose. They remained in this solution for two days in the dark at $25 \pm 2{ }^{\circ} \mathrm{C}$ under shaking at $80 \mathrm{rpm}$. The beads were dried on sterile paper filter to remove the liquid excess and then they were placed in a laminar flow cabinet for 30 min until reaching $80 \%$ humidity.

\section{Cryopreservation}

The cryopreservation techniques used were: (1) flashcooling by direct immersion in liquid nitrogen (LN) and (2) controlled-rate freezing with pre-cooling to a temperature of $-40{ }^{\circ} \mathrm{C}$, both followed by immersion in $\mathrm{LN}$. With both techniques, capsules remained in LN for 120 min; 80 capsules were used per treatment. Samples were placed in sterile cryotubes, with five beads in each.

For the controlled-rate freezing, a Mr. Frosty ${ }^{\circledR}$ Freezing Container (Nalgene) was used. The rate of cooling was set to $-1{ }^{\circ} \mathrm{C}$ per min. After $68 \mathrm{~min}$, the temperature reached $-40{ }^{\circ} \mathrm{C}$ (information provided by the manufacturer). Once the pre-freezing temperature was reached, the beads were immersed in LN $\left(-196^{\circ} \mathrm{C}\right)$ for $2 \mathrm{~h}$.

After $2 \mathrm{~h}$ in LN, the cryotubes were thawed in a water bath at of $37^{\circ} \mathrm{C}$ for $3 \mathrm{~min}$ (Walters et al., 2008). The beads were then placed in a sterile solution of $100 \mu \mathrm{M}$ $\mathrm{KNO}_{3}$ to remove the alginate.

\section{Assessing DNA integrity}

Total DNA of cryopreserved EA was extracted based on the CTAB 5\% protocol (Doyle \& Doyle, 1990), with slight modifications (Frizzo, 2013).

Fifteen axes were used for each treatment, divided into three groups of five. DNA quantification was realized using a NanoDrop 2000 spectrophotometer (Thermo Scientific). The samples were diluted to the same concentration (12ng $\mu \mathrm{L}^{-1}$ for each sample) and applied in a $0.8 \%$ agarose gel. Electrophoresis was performed for $30 \mathrm{~min}$ at $100 \mathrm{~W}$. DNA degradation was identified through the presence of drag. Total DNA was analyzed from non-encapsulated axes, encapsulated and not cryopreserved axes, as well as axes that were encapsulated and cryopreserved.

The DNA of embryonic axes removed from the seeds before the encapsulation procedure (samples 1, 5 and 9) were assessed to verify that the sodium alginate solution with an elevated concentration of sucrose did not cause a toxic effect on the axes. Due to the fact that the methods used herein included a stage in which the beads were dehydrated, we also assessed the total DNA of axes that were encapsulated, dehydrated in the laminar flow cabinet, and not cryopreserved (samples 2, 3 and 4). With these dehydrated samples, we sought to evaluate whether the process of rapid drying and the osmoprotection treatment could damage the DNA.

\section{Triphenyltetrazoliumchloride test}

Ten EA from each treatment were placed in a $1 \%$ 2,3,5-triphenyltetrazolium chloride solution for $2 \mathrm{~h}$, in the dark, at $30^{\circ} \mathrm{C}$ (Abreu et al., 2012). Afterwards, the EA were washed, dissected lengthwise, evaluated internally and, based on their coloration, classified as viable or not viable. For each treatment, non-encapsulated axes were used as control.

\section{In vitro germination}

The survival after cryopreservation was evaluated placing EA in test tubes $(15 \times 2.5 \mathrm{~cm})$ containing $15 \mathrm{~mL}$ of culture media. It was used MS medium supplemented with $4 \mathrm{~g} \mathrm{~L}^{-1}$ agar, 3\% activated charcoal, $0.929 \mathrm{mM}$ KIN (kinetin), and $11.40 \mathrm{mM}$ IAA (indoleacetic acid) (Pritchard \& Prendergast, 1986). The media $\mathrm{pH}$ was adjusted to 5.8 before autoclaving for $20 \mathrm{~min}$ at $120^{\circ} \mathrm{C}$. The test tubes were kept at $25 \pm 2{ }^{\circ} \mathrm{C}$ under an irradiance 
of $40 \mu \mathrm{mol} \mathrm{m} \mathrm{m}^{-2} \mathrm{~s}^{-1}$ and a $16 \mathrm{~h}$ photoperiod. Forty axes from each treatment were used. After 15 days, the rate of germination, the oxidation occurrence and the formation of calluses were evaluated. After 20 days in vitro, axes were removed from the culture medium in order to evaluate their morphological characteristics.

\section{Results}

\section{DNA integrity}

The electrophoresis profile of total DNA extracted from the araucaria embryonic axes that were not encapsulated, axes that were encapsulated but not cryopreserved, and those that were cryopreserved are shown in Figure 1.

The integrity of the total DNA was observed for all embryonic axes (EA) as there was no drag in any electrophoresis profile (Figure 1). This indicates that encapsulation, osmoprotection, rapid drying and cryopreservation did not damage the DNA of araucaria EA.

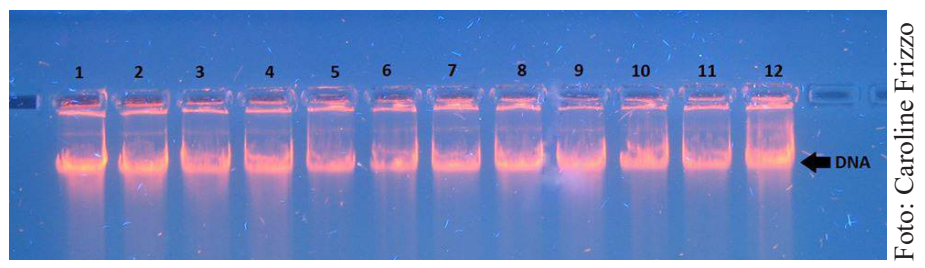

Figure 1. Electrophoresis of total DNA extracted from Araucaria angustifolia embryonic axes. 1, 5 and 9: axes excised before leading the experiment; 2, 3 and 4: not cryopreserved encapsulated axes; 6, 7 and 8: encapsulated axes submitted to flash-cooling; 10, 11, 12: encapsulated axes subjected to controlled-rate freezing.

\section{Tetrazolium test}

The EA were cut and internally assessed. The not cryopreserved encapsulated axes showed a red to pink color thus indicating that the embryos were viable, according to the tetrazolium test (Figure 2A). The radicle, hypocotyl and epicotyl exhibited a pink color, while the part that surrounds this set presented a red color. The majority of EA cryopreserved by flashcooling presented the same characteristics as the not cryopreserved, with the exception of the axes numbered 5 and 10; these were considered non-viable, as they presented a darker color (Figure 2B).
The EA cryopreserved using the pre-cooling method showed a red color darker when compared with the other samples (Figure 2C). This darker coloration indicates the beginning of deterioration and the consequent viability loss. None EA submitted to any of the three treatments showed signs of flaccid tissue. It is important to note that the not cryopreserved encapsulated axes were submerged in an osmoprotection solution with elevated concentrations of sucrose and then dehydrated, and even though they still appeared viable.

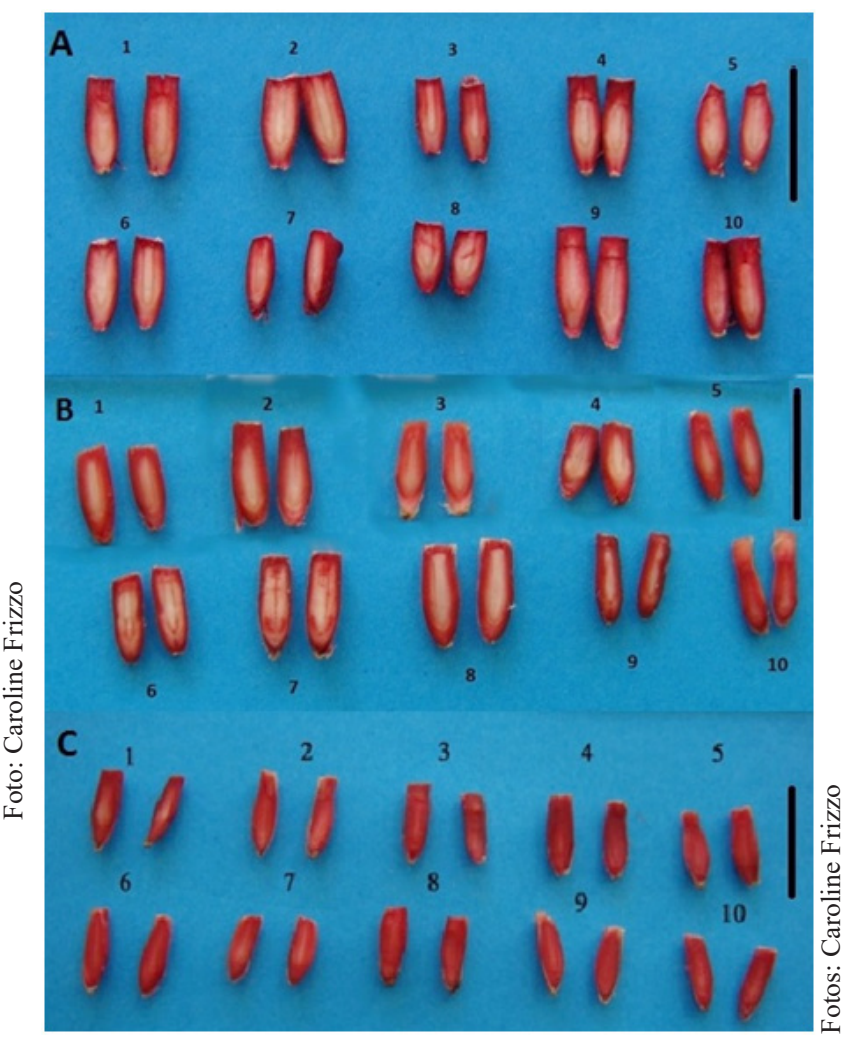

Figure 2. Araucaria angustifolia embryonic axes analyzed using the biochemical tetrazolium test. A: encapsulated but not cryopreserved axes; B: axes cryopreserved using the flashcooling method; $\mathrm{C}$ : axes cryopreserved with a pre-cooling phase. $\mathrm{Bar}=1 \mathrm{~cm}$.

\section{In vitro germination}

In relation to in vitro germination, only a small percentage of the encapsulated but not cryopreserved EA germinated (4\%), while none of the either pre-cooled or flash-cooled axes germinated (Table 1).

Despite remaining in an osmoprotection solution with elevated concentration of sugar for two days and $30 \mathrm{~min}$ in the laminar flow cabinet, the encapsulated but not cryopreserved control axes showed signs of 
callogenesis. The oxidation levels of these control samples were lower than those from flash-cooling, but higher than after pre-cooling treatment (Table 1). Some encapsulated and not cryopreserved axes showed signs of swelling, initial stretching, and a yellowish-green coloration, which indicates viability (Walters et al., 2008). The axes producing root, shoot elongation and with a green color were considered germinated. Callus formation on the upper extremity occurred in $25 \%$ of the axes that were encapsulated but not cryopreserved.

The formation of calluses, observed on some axes, demonstrates the significant variability among EA in relation to regeneration in vitro, since the seeds were collected from various mother trees in different locations. The encapsulated and flash-cooled axes did not show callus formation or signs of germination after 15 days of in vitro culture. Furthermore, the amount of oxidation was high (68.6\%; Table 1) when compared to other treatments.

Table 1. Callus formation, germination and oxidation in Araucaria angustifolia embryonic axes after cryopreservation (control: encapsulated axes without cryopreservation).

\begin{tabular}{ccccc}
\hline Treatment & $\begin{array}{c}\text { Callus } \\
\text { formation } \\
(\mathbf{\%})\end{array}$ & $\begin{array}{c}\text { Germination } \\
\mathbf{( \% )}\end{array}$ & $\begin{array}{c}\text { Oxidation } \\
\mathbf{( \% )}\end{array}$ \\
\hline Control & $25.0 \mathrm{a}$ & $4.0 \mathrm{a}$ & $13.0 \mathrm{~b}$ \\
Flash-cooling & $0.0 \mathrm{~b}$ & $0.0 \mathrm{~b}$ & $68.6 \mathrm{a}$ \\
Pre-cooling & $0.0 \mathrm{~b}$ & $0.0 \mathrm{~b}$ & $10.8 \mathrm{~b}$ \\
\hline
\end{tabular}

Means with the same letter in the column do not differ based on Tukey's test with $5 \%$ probability. *Axes that show oxidation.

\section{Discussion}

In assessing the reaction of Eugenia pleurantha seeds to dehydration, electrophoresis profiles of total DNA were used to determine levels of DNA degradation; for this analysis, total DNA was extracted after each stage of water content reduction in the seeds (Masetto et al., 2008). In this study, as cryopreservation is related to changes in water content, the hydration level of plant tissue is also affected and can lead to DNA denaturation. Thus, we used electrophoresis profiles to assess total DNA. Observing the formation of bands without drag, we can conclude that total DNA from embryonic axes (EA) that have been cryopreserved using both methods remains intact, with no differences between the two treatments.

Based on the tetrazolium test, the EA that were frozen using the flash-cooling method and the axes that were only encapsulated presented similar coloration. This indicates that the flash-cooling method is promising when compared to cryopreservation using a pre-cooling phase.

Direct immersion in liquid nitrogen (LN), or flash-cooling, induces intracellular freezing earlier in the process, which prevents rapid cell dehydration. Furthermore, the ice crystals that form within the cell are minuscule and do not cause any damage (Engelmann \& Dussert, 2013; Huebinger et al., 2016). As such, the EA with high water concentration that are flash-cooled could survive cryopreservation (Normah \& Makeen, 2008; Berjak \& Pammenter, 2013). Another study has shown that recovery of seedlings was achieved for EA of recalcitrant seeds of Quercus robur $(60 \%)$ that were flash-cooled (Berjak et al., 1999). In most biological systems, the lowest temperature of super cooling is the point of ice nucleation, which occurs at about $-40{ }^{\circ} \mathrm{C}$. At this temperature, water molecules form "ice embryos" that are of a critical size and thermodynamically capable of growing and forming into crystals (Thomson et al., 2015; Lo et al., 2017). Ice crystals affect the structural and osmotic integrity of cells causing physical ruptures and mechanical damage (Pammenter \& Berjak, 2014; Huebinger et al., 2016).

Considering that the tetrazolium test is a method for quick physiological quality evaluation, a suitable protocol based on the evaluation of synthetic seeds using this test has been developed. According to the Brazilian Ministry of Agriculture Rules for Seed Testing (Brasil, 2009), for araucaria seeds, the tetrazolium test should be carried out for the whole seed, while for synthetic seeds only an internal evaluation of EA is required (Abreu et al., 2012).

The recovery of cryopreserved tissue is a critical part of the cryopreservation process and it depends on, among other factors, the subsequent culture conditions (Walters et al., 2008; Edesi et al., 2017). Media enriched with plant growth regulators, such as kinetin and indoleacetic acid, were used in the growth and recovery phase for Araucaria hunsteinii embryos and a high rate of recovery was obtained (Pritchard \& Prendergast, 1986). In the present study, we tested the addition of abscisic acid to the osmoprotection solution for encapsulated araucaria axes and the death of plant material was demonstrated through both in vitro germination and DNA quality analyses (data not shown). For cryopreserved perennial species, regeneration of EA has been achieved after long periods 
of in vitro culture and incubation (Marin \& DuranVila, 1988). The MS medium (Murashige \& Skoog, 1962 ) is the most commonly used in cryopreservation studies (Normah \& Makeen, 2008); however, in using such medium, we must consider the particularities of each species and a specific recovery medium should be developed for cryopreserved tissues. Oxidation is the main cause of damage during cryopreservation (Pammenter \& Berjak, 2014; González-Benito et al., 2016; Zevallos et al., 2016). With the right conditions of in vitro germination, EA which have been cryopreserved using the best suitable method for this specie show high levels of recovery after months in incubation.

One of the most commonly used techniques for species with recalcitrant seeds has been the encapsulation of embryos after pre-culture in a solution with high concentration of sucrose, which dehydrates the plant material and removes most or all of the freezable water. Sucrose, when it infiltrates into plant tissues, helps to maintain viability during dehydration and freezing by stabilizing the cellular membranes (Sershen et al., 2016; Matsumoto, 2017). Moreover, by replacing the water content, sucrose maintains phospholipid membranes in the liquid crystalline phase and promotes the vitrification of the cytoplasm (Bandupriya et al., 2007). The majority of studies assessing encapsulation and dehydration of recalcitrant and intermediate species have had some success. Somatic embryos of Quercus suber L. that were encapsulated and exposed to sucrose, reaching dryness levels of $25 \%$ or $35 \%$ water content, followed by freezing in LN, maintained their viability (Fernandes et al., 2008). In the present study, the osmo conditioning of beads in a solution of sucrose did not affect the physiological quality of the EA, as shown through the DNA integrity and the tetrazolium test. The observed damage through oxidation was the result of the cryopreservation process but with the possibility of recovery.

Other factors, such as the use of cryoprotectants, the appropriate method of freezing and pre-conditioning for exposure to low temperatures, can contribute to the successful cryopreservation of EA. The use of cryoprotectant solutions containing glycerol, propanediol, ethylene glycol and dimethyl sulfoxide can reduce the damage caused by cooling; however, these compounds may have toxic effects, depending on the species and length of exposure (Walters et al., 2008; Su, 2016). Nadarajan et al. (2008) reported the successful cryopreservation of shoot tips of Parkia speciosa, which has large, highly metabolically active and recalcitrant seeds, difficult to cryopreserve. These authors showed that alginate encapsulation and the use of a combination of PVS2 (Plant vitrification solution 2) and trehalose had a synergistic effect and reduced the molecular mobility of water. This method could be an option for cryopreservation of Araucaria material.

Slow-thawing processes need further study as the rehydration of cells during quick-thawing can cause damage to the cellular membranes after cryopreservation. Another alternative to improve tolerance to freezing among temperate and subtropical species is the conditioning of plants to low temperatures, known as cold acclimation and cold-hardening (Reed \& Uchendu, 2008; Sinha et al., 2015). Cold acclimation likely activates genes that promote membrane stability (Kaczmarczyk et al., 2012; Menon et al., 2014). This technique could be used in the cryopreservation process of Araucaria angustifolia EA as it is a subtropical species.

\section{Conclusion}

A methodology for cryopreservation of araucaria embryonic axes remains elusive. However, we observed that cryopreservation of embryonic axes by flash-cooling appears to be more appropriate for this species than controlled-rate freezing.

\section{Acknowledgements}

The authors thank the Post-graduate Program in Agronomy - Crop Science, Universidade Federal do Paraná (UFPR), Coordenação de Aperfeiçoamento de Pessoal de Nível Superior (Capes), Elisa Serra Negra Vieira of Embrapa Florestas, Izulme Santos and Rosangela Caldas Mundin of Embrapa Recursos Genéticos e Biotecnologia, Brazil.

\section{References}

Abreu, D. C. A. et al. Teste Topográfico de tetrazólio em sementes de pinheiro-brasileiro (Araucaria angustifolia (Bertol.) Kuntze). In: CONGRESSO FLORESTAL PARANAENSE, 4., 2012, Curitiba. Anais...Curitiba: Malinovski Florestal, 2012.

Bandupriya, H. D. D. et al. Effect of abscisic acid on survival and recovery of cryopreserved plumule explants of Coconut (Cocos nulifera L.). Cocos, v. 18, p. 58-66, 2007. DOI: $10.4038 / \operatorname{cocos}$. v18i0.989. 
Berjak, P. et al. Experimental parameters underlying failure or success in plant germplasm cryopreservation: a case study on zygotic axes of Quercus robur L. CryoLetters, v. 20, p. 251-262, 1999.

Berjak, P. \& Pammenter, N. W. Implications of the lack of desiccation tolerance in recalcitrant seeds. Frontiers in Plant Science, v. 4, p. 1-9, 2013. DOI: 10.3389/fpls.2013.00478.

Brasil. Ministério da Agricultura, Pecuária e Abastecimento. Secretaria de Defesa Agropecuária. Regras para análise de sementes. Brasília, DF, 2009. 399 p.

Demarchi, G. et al. Ultra-low temperature conservation of Brazilian pine embryogenic cultures. Anais da Academia Brasileira de Ciências, v. 86, n. 4, p. 2057-2064, 2014. DOI: 10.1590/00013765201420130405 .

Doyle, J. J. \& Doyle, J. L. Isolation of plant DNA from fresh tissue. Focus, v. 12, p. 13-15, 1990.

Edesi, J. et al. Modified light spectral conditions prior to cryopreservation alter growth characteristics and cryopreservation success of potato (Solanum tuberosum L.) shoot tips in vitro. Plant Cell, Tissue and Organ Culture, v. 128, n. 2, p. 409-421, 2017. DOI: $10.1007 / \mathrm{s} 11240-016-1119-\mathrm{x}$.

Elbl, P. et al. Comparative transcriptoma analysis of early somatic embryo formation and seed development in Brazilian pine, Araucaria angustifolia (Bert.) Kuntze. Plant Cell Tissue and Organ Culture, v. 120 , n. 3, p. 903- 915, 2014. DOI 10.1007/s11240-014-0523-3.

Engelmann, F. \& Dussert, S. Cryopreservation. In: Normah, M. N. et al. Conservation of tropical plant species. New York: Springer, 2013. p. 107-119.

Fernandes, P. et al. Cryopreservation of Quercus suber somatic embryos by encapsulation-dehydration and evaluation of genetic stability. Tree Physiology, v. 28, n. 12, p. 1841-1850, 2008. DOI: 10.1093/treephys/28.12.1841.

Fraga, H. P. F. et al. High-efficiency cryopreservation of Araucaria angustifolia (Bertol.) Kuntze embryogenic cultures: ultrastructural characterization and morpho-physiological features. Plant Cell, Tissue and Organ Culture, v. 124, n. 2, p. 307-318, 2016. DOI: 10.1007/s11240-015-0895-z.

Frizzo, C. Comportamento de eixos embrionários de Araucária angustifolia Bertol (O. Kuntze) após a criopreservação, usando o método de encapsulamento-desidratação. 2013. 66 f. Dissertação (Mestrado em Agronomia) - Universidade Federal do Paraná, Curitiba.

Gasparin, E. et al. Physiological and ultrastructural responses during drying of recalcitrant seeds of Araucaria angustifolia. Seed Science and Technology, v. 45, n. 1, p. 112-129, 2017. DOI: 10.15258/ sst.2017.45.1.01.

González-Benito, M. E. et al. Effect of antioxidants on the genetic stability of cryopreserved mint shoot tips by encapsulationdehydration. Plant Cell, Tissue and Organ Culture, v. 127, n. 2, p. 359-368, 2016. DOI:10.1007/s11240-016-1056-8.

Huebinger, J. et al. Direct Measurement of water states in cryopreserved cells reveals tolerance toward ice crystallization. Biophysical Journal, v. 110, n. 4, p. 840-849, 2016. DOI: 10.1016/j. bpj.2015.09.029.
Jaganathan, G. K. et al. Physiological mechanisms only tell half story: multiple biological processes are involved in regulating freezing tolerance of imbibed Lactuca sativa seeds. Scientific Reports, v. 7, p. 1 - 14, 2017. DOI: 10.1038/srep44166.

Kaczmarczyk, A. et al. Current issues in plant cryopreservation. In: Katkov, I. (Ed.). Current frontiers in cryobiology. Rijeka: InTech, 2012. p. 417-438.

Kwaśniewska, E. et al. Integration of cryopreservation and tissue culture for germplasm conservation and propagation of Rosa pomifera 'Karpatia'. Notulae Botanicae Horti Agrobotanici ClujNapoca, v. 45, n. 1, p. 208-214, 2017. DOI: 10.15835/nbha45110566.

Lo, C. W. et al. Control of ice formation. ACS nano, v. 11, n. 3, p. 2665-2674, 2017. DOI: 10.1021/acsnano.6b07348.

Maran, J. C. et al. Survival and germination analysis in plantations of Araucaria angustifolia derived from seedlings and seeds. Ciência Florestal, v. 26, n. 4, p. 1349-1360, 2016. DOI: 10.5902/1980509825154.

Marin, M. L. \& Duran-Vila, N. Survival of somatic embryos and recovery of plants of sweet orange (Citrus sinensis (L.) Osb.) after immersion in liquid nitrogen. Plant Cell, Tissue and Organ Culture, v. 14, n. 1, p. $51-57,1988$.

Masetto, T. E. et al. Desiccation tolerance and DNA integrity in Eugenia pleurantha O. Berg. (Myrtaceae) seeds. Revista Brasileira de Sementes, v. 30 , n. 2, p. 51-56, 2008. DOI: 10.1590/S010131222008000200007 .

Matsumoto, T. Cryopreservation of plant genetic resources: conventional and new methods. Reviews in Agricultural Science, v. 5, p. 13-20, 2017. DOI: 10.7831/ras5.13.

Menon, A. et al. Cold-induced changes affect survival after exposure to vitrification solution during cryopreservation in the south-west Australian Mediterranean climate species Lomandra sonderi (Asparagaceae). Plant Cell, Tissue and Organ Culture, v. 119, n. 2, p. 347-358, 2014. DOI 10.1007/s11240-014-0538-9.

Murashige, T. \& Skoog, F. A revised medium for rapid growth and bioassay with tobacco tissue cultures. Physiologia Plantarum, v. 15, n. 3, p. 473-497, 1962. DOI: 10.1111/j.1399-3054.1962.tb08052.x.

Nadarajan, J. et al. Applications of differential scanning calorimetry in developing cryopreservation strategies for Parkia speciosa, a tropical tree producing recalcitrant seeds. CryoLetters, v. 29, n. 2, p. 95-110, 2008.

Niino, T. \& Arizaga, M. V. Cryopreservation for preservation of potato genetic resources. Breeding science, v. 65, n. 1, p. 41-52, 2015. DOI: $10.1270 /$ jsbbs.65.41

Normah, M. N. \& Makeen, A. M. Cryopreservation of excised embryos and embryonic axes. In: Reed, B. M. (Ed.). Plant cryopreservation: a practical guide. New York: Springer, 2008, p. 211-240.

Pammenter, N. W. \& Berjak, P. Physiology of desiccation-sensitive (recalcitrant) seeds and the implications for cryopreservation. International Journal of Plant Sciences, v. 175, n. 1, p. 21-28, 2014. DOI: $10.1086 / 673302$. 
Pelissari, A. L. et al. Estrutura espacial arbórea de um remanescente natural de floresta ombrófila mista. Biofix Scientific Journal, v. 1, n. 1, p. 27-32, 2016. DOI: 10.5380/biofix.v1i1.49094.

Pieruzzi, F. P. et al. Cryopreservation of embryogenic cell lines of Araucaria angustifolia (Bert.) O. Kuntze. Cryobiology, v. 63, p. 339, 2011. DOI: 10.1016/j.cryobiol.2011.09.122.

Pritchard, H. W. \& Prendergast, F. G. Effects of desiccation and cryopreservation on the in vitro viability of embryos of the recalcitrant seed species Araucaria hunsteinii K. Schum. Journal of Experimental Botany, v. 37, n. 9, p. 1388-1397, 1986. DOI: 10.1093/jxb/37.9.1388.

Reed, B. M. \& Uchendu, E. Controlled rate cooling. In: Reed, B. M. (Ed.) Plant Cryopreservation: a practical guide. New York: Springer, 2008. p. 77-92.

Santos, I. R. I. Criopreservação de germoplasma vegetal: a alternativa para a conservação a longo prazo. Biotecnologia, Ciência \& Desenvolvimento, n. 20, p. 1-24, 2001.

Sershen, et al. The use of plant stress biomarkers in assessing the effects of desiccation in zygotic embryos from recalcitrant seeds: challenges and considerations. Plant Biology, v. 18, n. 3, p. 433-444, 2016. DOI: $10.1111 /$ plb.12428.

Shahab, M. A. N. et al. Cryopreservation of Smirnovia iranica (Sabeti) seeds and evaluation of cryopreserved seeds under laboratory, greenhouse and natural habitat conditions. Journal of Rangeland Science, v. 7, n. 2, p. 122-137, 2017.

Shibli, R. A. et al. Experimenting two cryopreservation techniques (vitrification and encapsulation-dehydration) as approaches for long-term conservation of in vitro grown shoot tips of wild fennel. Jordan Journal of Biological Sciences, v. 9, n. 3, p. 147-154, 2016.
Sinha, S. et al. The omics of cold stress responses in plants. In: Pandey, G. K. (Ed.). Elucidation of abiotic stress signaling in plants. New York: Springer, 2015. p. 143-194. DOI: 10.1007/9781-4939-2540-7_6.

$\mathrm{Su}, \mathrm{C}$. et al. Novel glyceryl glucoside is a low toxic alternative for cryopreservation agent. Biochemical and Biophysical Research Communications, v. 476, n. 4, p. 359-364, 2016. DOI: 10.1016/j. bbrc.2016.05.127.

Tahtamouni, R. et al. In vitro conservation and cryopreservation of medicinal and aromatic plants: a review. Jordan Journal of Biological Sciences, v. 11, p. 147-167, 2015.

Thomas, P. Araucaria angustifolia. In: The IUCN red list of threatened species 2013: e.T32975A2829141. DOI: 10.2305/IUCN. UK.2013-1.RLTS.T32975A2829141.en.

Thomson, E. S. et al. Deposition-mode ice nucleation reexamined at temperatures below $200 \mathrm{~K}$. Atmospheric Chemistry and Physics, v. 15, n. 4, p. 1621-1632, 2015. DOI: 10.5194/acp-15-1621-2015.

Walters, C. et al. Cryopreservation of recalcitrant (i.e. desiccationsensitive) seeds. In: Reed, B. M. (Ed.). Plant cryopreservation: a practical guide. Nova York: Springer, 2008. p. 465-484.

Zanette, F. et al. Particularidades e biologia reprodutiva de Araucaria angustifolia. In: Zanette, F. \& Wendling, I. (Ed.). Araucária: particularidades, propagação e manejo de plantios. Brasília, DF: Embrapa, 2017. p. 15-30.

Zevallos, B. et al. Biochemical characterization of ecuadorian wild Solanum lycopersicum Mill. plants produced from non-cryopreserved and cryopreserved seeds. CryoLetters, v. 37, n. 4, p. 413-421, 2013. 